\title{
Bacteriolytic Activity of Seminalplasmin
}

\author{
By SANJAY N. CHITNIS, KOLLIS. N. PRASAD AND \\ PUSHPA M. BHARGAVA* \\ Centre for Cellular and Molecular Biology, Hyderabad 500007, India
}

\author{
(Received 11 November 1987)
}

\begin{abstract}
Seminalplasmin, an antimicrobial protein from bovine seminal plasma, lysed both Grampositive and Gram-negative bacteria but not Candida albicans. The lytic activity was not lysozyme-like and was not affected by inhibitors of RNA or protein synthesis or by azide; it was strongly inhibited by divalent cations like $\mathrm{Ca}^{2+}, \mathrm{Mn}^{2+}$ and $\mathrm{Mg}^{2+}$ at millimolar concentrations. Maximum lysis of Escherichia coli was obtained at $37^{\circ} \mathrm{C}$; heat treatment of $E$. coli drastically reduced its susceptibility to lysis by seminalplasmin. $E$. coli cells in the stationary phase of growth were lysed much less than those in the exponential phase, and those grown in an enriched medium were lysed much more than those grown in a minimal medium. It appears that the lytic activity of seminalplasmin is due to the activation of an autolysin.
\end{abstract}

\section{INTRODUCTION}

Seminalplasmin is an antimicrobial protein isolated from bovine seminal plasma (Reddy \& Bhargava, 1979). It inhibits the growth of many Gram-positive and Gram-negative bacteria and yeasts by entering the cells and inhibiting RNA synthesis (Reddy \& Bhargava, 1979; Bhargava, $1981 a, b$; Shivaji, 1984; Rao \& Bhargava, 1985; Scheit \& Bhargava, 1985; Scheit et al., 1985). In vitro, seminalplasmin binds to RNA polymerases and reverse transcriptases and inhibits their activity (Scheit et al., 1979; Rao et al., 1983; Reddy et al., 1983; Scheit \& Zimmer, 1984). We now report that concentrations of seminalplasmin higher than those required for the inhibition of RNA synthesis lyse Escherichia coli cells. The lysis may be the result of the activation of an autolysin.

\section{METHODS}

Micro-organisms, media and reagents. E. coli strain C90 (Bachmann, 1972), which is inducible for $\beta$ galactosidase, Bacillus subtilis NCIM 2162, and Candida albicans NCIM 3100, obtained from the National Collection of Industrial Micro-organisms (NCIM), Poona, India, were used. E. coli and B. subtilis were grown at $37^{\circ} \mathrm{C}$ in glucose-minimal A medium (Miller, 1972) with $0.1 \mathrm{~mm}-\mathrm{MgSO}_{4}$, unless stated otherwise. C. albicans was grown at $30^{\circ} \mathrm{C}$ in a yeast extract/glucose medium $(1 \%, w / v$, yeast extract $/ 3 \%, w / v$, glucose). Dried cells of Micrococcus luteus and protease type XI were obtained from Sigma. Seminalplasmin and antiseminalplasmin were prepared from bovine seminal plasma as described earlier (Reddy \& Bhargava, 1979; Rao \& Bhargava, 1985).

Lytic activity of seminalplasmin. This was measured by following the decrease in optical density at $600 \mathrm{~nm}$ $\left(\mathrm{OD}_{600}\right)$ of microbial cells, grown to exponential phase except where indicated, initially suspended at an $\mathrm{OD}_{600}$ of $0 \cdot 15-0 \cdot 3\left(1 \cdot 5-3.0 \times 10^{8}\right.$ cells $\mathrm{ml}^{-1}$ ) in either minimal medium containing $0 \cdot 1 \mathrm{~mm}-\mathrm{Mg}^{2+}$ (which medium was used unless otherwise mentioned), or Tris/ $\mathrm{HCl}$ buffer $(10 \mathrm{mM} ; \mathrm{pH} 7 \cdot 4)$ containing $0 \cdot 1 \mathrm{M}-\mathrm{NaCl}$, and incubated with the desired amount of seminalplasmin at $37^{\circ} \mathrm{C}$ (unless otherwise stated) for the desired period. Seminalplasmin dissolved in $20-40 \mu$ l distilled water was added to $1 \mathrm{ml}$ of the cell suspension; addition of this amount of water alone had no lytic effect. In some cases in which the medium used for studying lysis was different from that used for growth, the cells were sedimented by centrifugation and resuspended in the desired medium. This treatment did not result in any cell lysis.

The kinetics of lysis by seminalplasmin was studied either by periodic measurements of $\mathrm{OD}_{600}$, or by recording continuously the decrease in $\mathrm{OD}_{600}$ of cells incubated with seminalplasmin in a cuvette maintained at $37^{\circ} \mathrm{C}$.

$R N A$ synthesis. This was studied either by pulse labelling or by continuous labelling. For pulse labelling, E. coli 


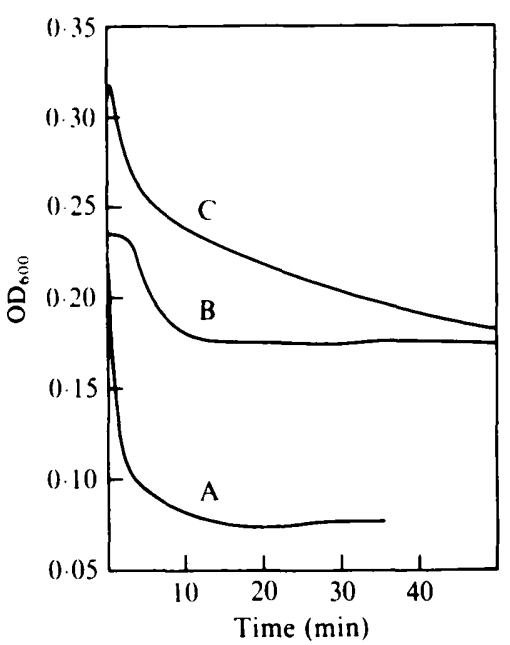

Fig. 1

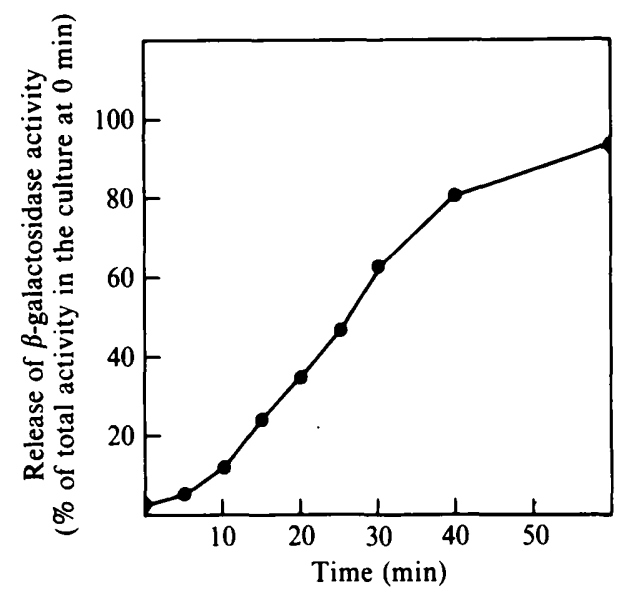

Fig. 2

Fig. 1. Kinetics of the lysis of viable $E$. coli $(A$ and $B)$ and B. subtilis $(C)$ cells by seminalplasmin $(200 \mu \mathrm{g}$ $\mathrm{ml}^{-1}$ ). E. coli cells were grown in LB medium (A) or minimal medium (B), and B. subtilis cells in minimal medium. The cells were sedimented in a microcentrifuge for $15 \mathrm{~min}$ and resuspended in minimal medium, and lysis was followed by continuously recording the $\mathrm{OD}_{600}$.

Fig. 2. Kinetics of the release of $\beta$-galactosidase from $E$. coli cells treated with seminalplasmin $(200 \mu \mathrm{g}$ $\left.\mathrm{ml}^{-1}\right)$. The cells were grown in minimal medium containing $0.4 \%(\mathrm{w} / \mathrm{v})$ lactose and incubated with seminalplasmin at $37^{\circ} \mathrm{C}$. Samples of $0.1 \mathrm{ml}$ taken at different times were diluted to $1 \mathrm{ml}$ with cold minimal medium and spun down at $120000 \mathrm{~g}$ for $15 \mathrm{~min}$ at $4^{\circ} \mathrm{C}$. $\beta$-Galactosidase activity was determined in the cell-free supernatant as described in Methods. The $\mathrm{OD}_{600}$ of the culture incubated with seminalplasmin was 0.25 at $0 \mathrm{~min}$ and 0.06 at $60 \mathrm{~min}$.

cells were suspended at an $\mathrm{OD}_{600}$ of 0.3 in $1 \mathrm{ml}$ minimal medium containing $0.1 \mathrm{mM}-\mathrm{Mg}^{2+}$, and incubated at $37^{\circ} \mathrm{C}$. At various times, a $0.1 \mathrm{ml}$ sample of the culture was pulse-labelled with $\left[{ }^{3} \mathrm{H}\right]$ uridine $[20 \mu \mathrm{Ci}(740 \mathrm{kBq})$; sp. act. 14 $\left.\mathrm{Ci} \mathrm{mmol}{ }^{-1}\left(518 \mathrm{GBq} \mathrm{mmol}^{-1}\right)\right]$ for $20 \mathrm{~s}$ at $37^{\circ} \mathrm{C}$. Cold $10 \%$ (w/v) trichloroacetic acid (TCA, $1 \mathrm{ml}$ ) was added followed by bovine serum albumin $(0.5 \mathrm{mg})$, and the TCA-insoluble material was collected on Whatman no. 1 filter paper discs, washed with cold $5 \%$ TCA, dried and counted in a toluene-based scintillation fluid. For continuous labelling, $E$. coli cells $\left(\mathrm{OD}_{600} 0.3\right)$ were incubated with [ $\left.{ }^{3} \mathrm{H}\right]$ uridine $\left[200 \mu \mathrm{Ci}(7.4 \mathrm{MBq}) \mathrm{ml}^{-1}\right.$; sp. act. $14 \mathrm{Ci} \mathrm{mmol}^{-1}$ ]at $37^{\circ} \mathrm{C}$ in minimal medium containing $0.1 \mathrm{~mm}-\mathrm{Mg}^{2+}$. At various times, $0.1 \mathrm{ml} \mathrm{samples} \mathrm{of} \mathrm{the} \mathrm{culture}$ were processed as above.

$\beta$-Galactosidase activity. This was measured in the cell supernatant using $o$-nitrophenyl- $\beta$-galactoside as the substrate (Miller, 1972); the total enzyme activity in the culture was measured after toluenization of the cells.

\section{RESULTS}

Cells of $E$. coli growing exponentially were lysed by seminalplasmin (Fig. 1). In a large number

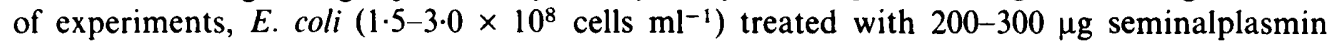
$\mathrm{ml}^{-1}$ showed a $25-90 \%$ decrease in $\mathrm{OD}_{600}$ in 1-2 $\mathrm{h}$. The time course of lysis by seminalplasmin was similar to that of autolysis induced by agents such as EDTA in showing an initial exponential phase followed by a plateau (Leduc \& Van Heijenoort, 1980; Leduc et al., 1982). Lysis of $E$. coli was also demonstrated by measurement of the release of $\beta$-galactosidase from cells in which the enzyme has been induced by growth in lactose-minimal A medium (Fig. 2).

$E$. coli cells grown in an enriched medium (LB; Miller, 1972) were significantly more susceptible to lysis than cells grown in minimal medium (Fig. 1). (Assays for lysis were done only in minimal medium, irrespective of the medium in which the cells had been grown, since cells suspended in the enriched medium were not lysed at all by seminalplasmin, presumably due to degradation or complexing of seminalplasmin by the constituents of the medium.) Dense cell suspensions $\left(10^{9}-10^{10}\right.$ cells $\left.\mathrm{ml}^{-1}\right)$ were also lysed by seminalplasmin, provided that higher 


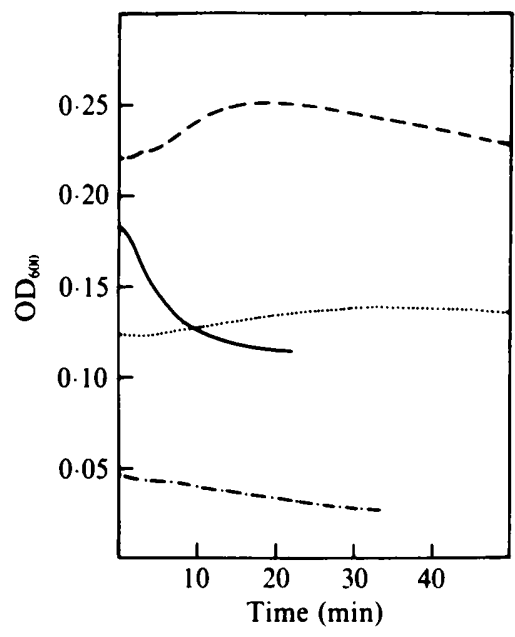

Fig. 3

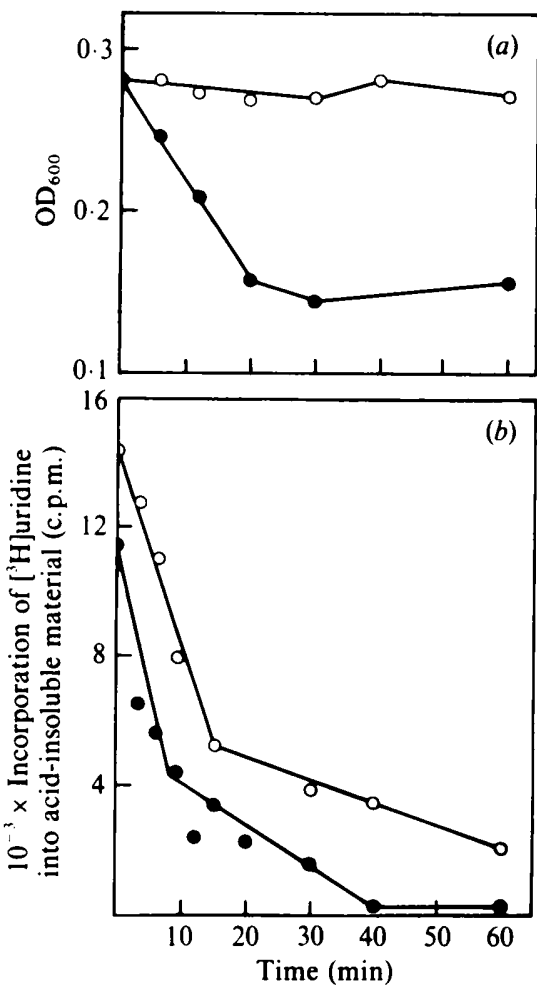

Fig. 4

Fig. 3. Effect of $\mathrm{pH}$ on the lysis of $E$. coli cells by seminalplasmin $\left(200 \mu \mathrm{g} \mathrm{ml}^{-1}\right)$. Cells were grown in minimal medium containing $10 \mathrm{mM}$-citrate adjusted to $\mathrm{pH} 5.0$ or 7.5 , sedimented in a microcentrifuge for $10 \mathrm{~min}$ and resuspended in the above medium at $\mathrm{pH} 5.0$ or 7.5 , and lysis was followed by continuous recording of $\mathrm{OD}_{600}$. Cells grown and lysed at $\mathrm{pH} 7.5 ;---$, cells grown at $\mathrm{pH} 7.5$ and lysed at pH $5 \cdot 0 ; \cdots \cdot$, cells grown and lysed at $\mathrm{pH} 5.0 ;-\cdot-\cdot$, cells grown at $\mathrm{pH} 5.0$ and lysed at $\mathrm{pH} 7.5$.

Fig. 4. Comparison of the kinetics of lysis $(a)$ and of the inhibition of RNA synthesis (b) by seminalplasmin in exponentially growing $E$. coli cells. $\bigcirc, 100 \mu \mathrm{g}$ seminalplasmin $\mathrm{ml}^{-1} ; 0,200 \mu \mathrm{g}$ seminalplasmin $\mathrm{ml}^{-1}$. RNA synthesis was studied by pulse labelling as described in Methods. Lysis was followed by measuring the $\mathrm{OD}_{600}$ at various time intervals.

concentrations (about $1-2 \mathrm{mg} \mathrm{ml}^{-1}$ ) of the protein were used. $B$. subtilis cells grown in minimal medium were also lysed by seminalplasmin, the kinetics of lysis being similar to that observed in the case of $E$. coli (Fig. 1). Cells of $C$. albicans (which is susceptible to growth inhibition by seminalplasmin; Scheit \& Bhargava, 1985) or dried cells of $M$. luteus were not lysed even by high concentrations $\left(400 \mu \mathrm{g} \mathrm{ml}^{-1}\right)$ of seminalplasmin.

$E$. coli cells grown at $\mathrm{pH} 5.0$ were much less susceptible to lysis by seminalplasmin, at $\mathrm{pH} 5.0$ or $\mathrm{pH} 7 \cdot 5$, than were those grown at $\mathrm{pH} 7.5$ (Fig. 3). The lytic activity of seminalplasmin was much less pronounced at $\mathrm{pH} 5.0$ than at $\mathrm{pH} 7.5$ for cells grown at either $\mathrm{pH}$ (Fig. 3). In this regard, seminalplasmin-induced lysis is similar to penicillin-induced lysis (Goodell et al., 1976).

Seminalplasmin inhibits RNA synthesis in E. coli and other micro-organisms (Reddy \& Bhargava, 1979; Bhargava, 1981 a, b; Shivaji, 1984; Scheit \& Bhargava, 1985; Scheit et al., 1985). To determine whether the inhibition of RNA synthesis by seminalplasmin is a consequence of the lysis of cells, we looked at the time course of both processes, at two seminalplasmin concentrations (Fig. 4); at the lower concentration $\left(100 \mu \mathrm{g} \mathrm{ml}^{-1}\right)$, at which seminalplasmin dramatically inhibited growth of and RNA synthesis in $E$. coli, no significant lysis was observed. Further, $E$. coli cells in the stationary phase of growth seemed to be far less susceptible to lysis by seminalplasmin than exponentially growing cells (Fig. 5); the rate of RNA 


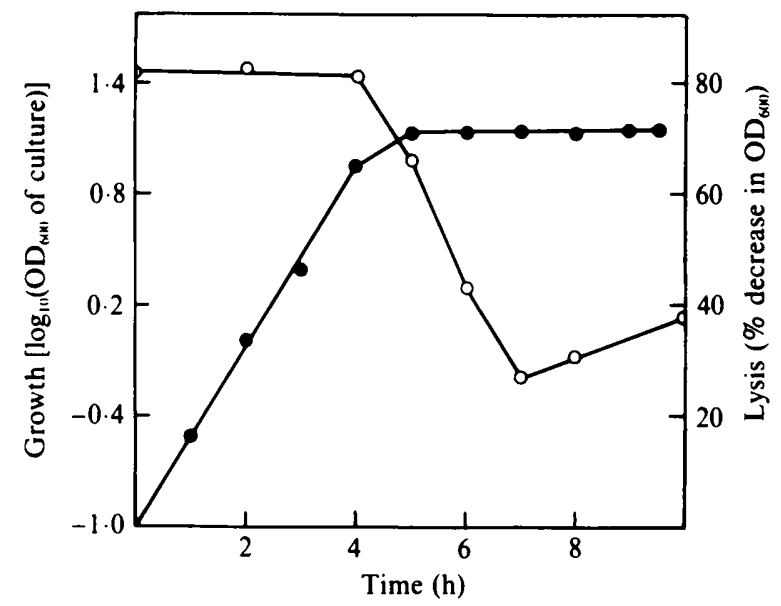

Fig. 5. Lytic effect of seminalplasmin $\left(200 \mu \mathrm{g} \mathrm{ml}^{-1}\right)$ on $E$. coli at various stages of growth. A sample of the growing culture was diluted with minimal medium to $\mathrm{OD}_{600} 0.20$ before the addition of seminalplasmin, and lysis was followed by measurement of the decrease in $\mathrm{OD}_{600}$ after incubation for 1 h. Growth; O, lysis.

synthesis in stationary phase cells, on the other hand, was sensitive to inhibition by seminalplasmin (inhibition $\simeq 45 \%$ with $100 \mu \mathrm{g} \mathrm{ml}^{-1}$ and $\simeq 70 \%$ with $200 \mu \mathrm{g} \mathrm{ml}^{-1}$ at $12 \mathrm{~min}$, beyond which no further RNA synthesis took place in the presence of seminalplasmin; not shown).

The lysis by seminalplasmin of $E$. coli cells $\left(\mathrm{OD}_{600} 0 \cdot 2\right)$ killed by heating for $15 \mathrm{~min}$ at $80^{\circ} \mathrm{C}$ was $16 \%$ of that observed with cells that were not heat-treated. However, seminalplasmin lysed $E$. coli cells that had been killed by a $2 \mathrm{~h}$ treatment with rifampicin $\left(50 \mu \mathrm{g} \mathrm{m}^{-1}\right)$, with the same efficiency as it lysed exponentially growing viable cells. The optimum temperature for the lysis of $E$. coli cells by seminalplasmin was $37^{\circ} \mathrm{C}$; lysis at $0{ }^{\circ} \mathrm{C}$ was $30.3 \%$ and at $55^{\circ} \mathrm{C}, 8.2 \%$ of that at $37^{\circ} \mathrm{C}$.

Seminalplasmin inhibits RNA synthesis in various micro-organisms, and subsequently kills them (Reddy \& Bhargava, 1979; Scheit \& Bhargava, 1985; Scheit et al., 1985). Antiseminalplasmin, another protein isolated from bovine seminal fluid, reverses the inhibition of growth and of RNA synthesis by seminalplasmin by preventing the latter's entry into the cells (Rao \& Bhargava, 1985). Antiseminalplasmin $\left(200 \mu \mathrm{g} \mathrm{ml}^{-1}\right)$ inhibited the lytic activity of seminalplasmin even if added during the course of lysis (Fig. 6). We have recently shown that calcium ions, too, reverse the inhibitory effects of seminalplasmin (N. Sitaram, K. H. Scheit and P. M. Bhargava, unpublished); $\mathrm{Ca}^{2+}$ and other divalent cations also inhibited the lytic activity of seminalplasmin (Fig. 7).

The protein synthesis inhibitor chloramphenicol $\left(200 \mu \mathrm{g} \mathrm{ml}^{-1}\right)$, and the respiratory inhibitor azide $\left(1 \mathrm{mg} \mathrm{ml}^{-1}\right)$, had no effect on the lysis of $E$. coli cells by seminalplasmin even when the cells were preincubated with the above agents for $30 \mathrm{~min}$ before being treated with seminalplasmin; lysis (measured after $1 \mathrm{~h}$ ) was, in fact, stimulated by about $50 \%$ in both cases. Under the same conditions, the non-specific protease type XI (Sigma; $500 \mu \mathrm{g} \mathrm{ml}^{-1}$ ) totally abolished the lytic activity of seminalplasmin. In a medium of high osmolarity $(0.5 \mathrm{M}$-sucrose or mannitol in minimal medium), the lysis of $E$. coli by seminalplasmin after $1 \mathrm{~h}$ was $60 \%$ more than that in the normal medium; no protoplasts or ghosts were formed even in the high-osmolarity medium.

\section{DISCUSSION}

We demonstrate here that seminalplasmin possesses bacteriolytic activity. Since this protein has an $M_{\mathrm{r}}$ of about 6000 (Theil \& Scheit, 1983), it can be calculated from the data given above that for lysis to occur, about $10^{8}$ molecules of seminalplasmin per $E$. coli cell need to be present in the incubation medium. As dried $M$. luteus cells, which act as an excellent substrate for 


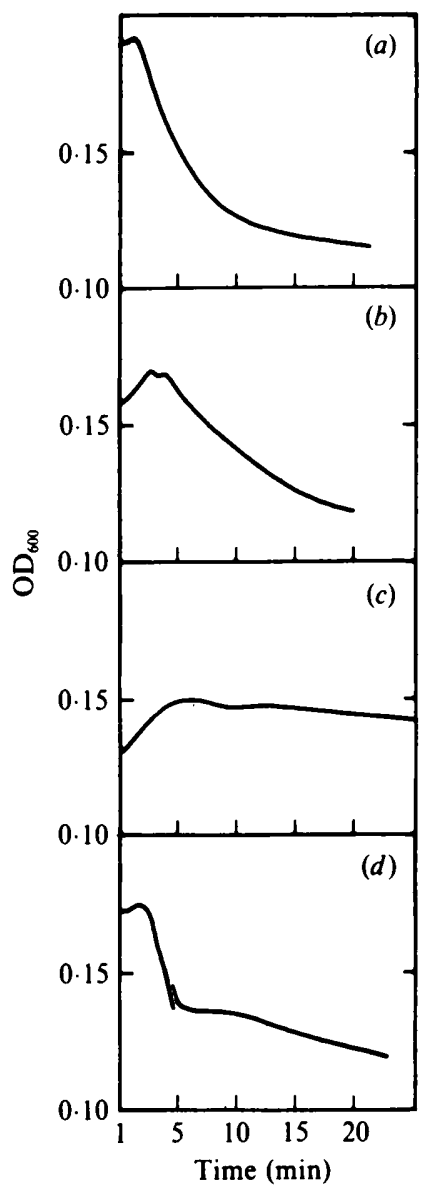

Fig. 6

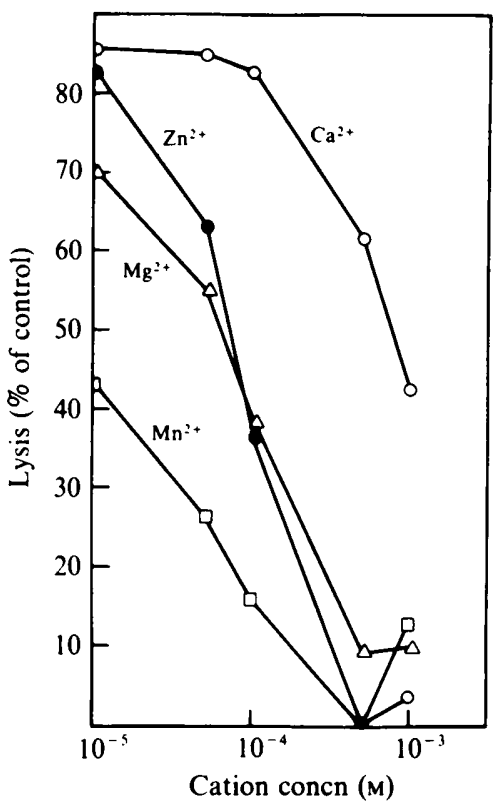

Fig. 7

Fig. 6. Effect of antiseminalplasmin on the lysis of $E$. coli cells by seminalplasmin $\left(200 \mu \mathrm{g} \mathrm{ml}^{-1}\right)$. Cells grown in minimal medium were treated with seminalplasmin and lysis was followed by continuous recording of $\mathrm{OD}_{600}$. Antiseminalplasmin was added at the times stated after the addition of seminalplasmin: (a) no antiseminalplasmin added; (b) antiseminalplasmin $\left(200 \mu \mathrm{g} \mathrm{ml}^{-1}\right)$ added at $0 \mathrm{~min}$; (c) antiseminalplasmin $\left(400 \mu \mathrm{g} \mathrm{ml}^{-1}\right)$ added at $0 \mathrm{~min} ;(d)$ antiseminalplasmin $\left(200 \mu \mathrm{g} \mathrm{ml}^{-1}\right)$ added at $5 \mathrm{~min}$.

Fig. 7. Effect of divalent cations on the lysis of $E$. coli cells by seminalplasmin $\left(200 \mu \mathrm{g} \mathrm{ml}^{-1}\right)$ in Tris/HCl buffer containing $0 \cdot 1 \mathrm{M}-\mathrm{NaCl}$. Lysis was followed by measurement of the decrease in $\mathrm{OD}_{600}$ over $1 \mathrm{~h}$. In the control (no added cation), there was a $60 \%$ reduction in $\mathrm{OD}_{600}$ over the initial value of 0.2 .

lysozyme, were not lysed, it is clear that the lytic activity of seminalplasmin is not like that of lysozyme.

Seminalplasmin is known to inhibit RNA synthesis in bacteria and yeasts. We show here that higher concentrations of seminalplasmin are required for lysis than for the inhibition of RNA synthesis. Further, seminalplasmin inhibits RNA synthesis in, but does not lyse, cells in the stationary phase of growth. It would therefore appear that the two effects of seminalplasmin - that is, the inhibition of RNA synthesis that eventually leads to death of the cell without lysis, and the lytic effect - are independent of each other.

The observation that lysis begins almost immediately after the addition of seminalplasmin would suggest that the lytic activity of seminalplasmin involves the cell wall. Agents such as $\beta$ lysin that lyse bacteria by affecting the cell membrane lead to a decrease in the optical density of the culture only after several hours even though some of the cellular constituents leak out at an 
early stage (Matheson \& Donaldson, 1968; Donaldson \& Tew, 1977). Apart from colicin M (Schaller et al., 1982), seminalplasmin is the only protein known to lyse a Gram-negative bacterium like $E$. coli in the absence of agents such as EDTA. It also lyses the Gram-positive organism $B$. subtilis.

Active uptake of seminalplasmin does not seem to be required for lysis of E. coli, as the lysis was not inhibited by azide. Nor did protein synthesis appear to be necessary, since chloramphenicol or rifampicin-treated cells were lysed as rapidly as (or more rapidly than) untreated cells. In this respect, lysis by seminalplasmin resembles EDTA-induced lysis and differs from lysis by agents such as penicillin (Leduc et al., 1982). Existing evidence strongly suggests that seminalplasmin kills micro-organisms by entering the cell and inhibiting RNA synthesis (Reddy \& Bhargava, 1979; Scheit \& Bhargava, 1985; Scheit et al., 1985). Inhibition of seminalplasmin-induced lysis of $E$. coli by antiseminalplasmin and $\mathrm{Ca}^{2+}$, which appear to prevent the entry of seminalplasmin into the cells (Rao \& Bhargava, 1985; N. Sitaram, K. H. Scheit \& P. M. Bhargava, unpublished), also suggests that the permeation of seminalplasmin, at least through the outer membrane, is required for lysis.

With regard to the mechanism of the lysis of $E$. coli by seminalplasmin there are two possibilities : seminalplasmin may lyse the cells directly as, for example, lysozyme does, or it may lead, directly or indirectly, to the activation of an autolysin. The first possibility would seem unlikely as seminalplasmin had no effect on heat-treated $E$. coli or dried $M$. luteus cells. The latter possibility is supported by the following observations: $(a)$ as in the case of autolysis induced by various methods (Leduc \& Van Heijenoort, 1980; Leduc et al., 1982; Lubitz et al., 1984), lysis by seminalplasmin of cells grown in rich medium was greater than that of cells grown in minimal medium, and lysis of cells in the stationary phase was less than that of exponentially growing cells; and $(b)$ like penicillin-induced lysis, seminalplasmin-induced lysis was much less pronounced when cells were grown at $\mathrm{pH} 5 \cdot 0$, or lysis was carried out at $\mathrm{pH} 5 \cdot 0$, than at higher $\mathrm{pH}$. We are at present in the process of isolating seminalplasmin-resistant mutants, which may allow us to test this possibility. If seminalplasmin does indeed activate an autolysin, the observation that cells preincubated with rifampicin for $2 \mathrm{~h}$ were lysed by seminalplasmin would suggest that the autolysin has a long half-life.

Seminalplasmin, unlike EDTA, does not bind to divalent cations such as $\mathrm{Ca}^{2+}$ (N. Sitaram, K. H. Scheit \& P. M. Bhargava, unpublished); its use may, therefore, be preferable to that of lysozyme for lysis of $E$. coli under certain conditions because the latter requires EDTA for its action.

\section{REFERENCES}

Bachmann, B. J. (1972). Pedigrees of some mutant strains of Escherichia coli K-12. Bacteriological Reviews 36, 525-557.

Bhargava, P. M. (1981a). Four new and unusual proteins from bovine seminal plasma. Biochemical Society Transactions 9, 540-543.

Bhargava, P. M. $(1981 b)$. The romance of the seminal fluid: the excitement of the unusual. Proceedings of the National Academy of Sciences of India Annual Number, 51-67.

Donaldson, D. M. \& TEW, J. G. (1977). $\beta$-Lysin of platelet origin. Bacteriological Reviews 41, 501-513.

GoOdell, E. W., Lopez, R. \& Tomasz, A. (1976). Suppression of lytic effect of $\beta$-lactams on Escherichia coli and other bacteria. Proceedings of the National Academy of Sciences of the United States of America 73, 3293-3297.

Leduc, M. \& VAN Heijenoort, J. (1980). Autolysis of Escherichia coli. Journal of Bacteriology 142, 52-59.

LedUC, M., KasRa, R. \& VAN HeIJenOORT, J. (1982). Induction and control of the autolytic system of Escherichia coli. Journal of Bacteriology 152, 26-34.
Lubitz, W., HalfmanN, G. \& Plapp, R. (1984). Lysis of Escherichia coli after infection with $\phi \times 174$ depends on the regulation of the cellular autolytic system. Journal of General Microbiology 130, 10791087.

Matheson; A. \& Donaldson, D. M. (1968). Alterations in the morphology of Bacillus subtilis after exposure to $\beta$-lysin and ultraviolet light. Journal of Bacteriology 95, 1892-1902.

Miller, J. H. (1972). Experiments in Molecular Genetics, pp. 353, 432-433. Cold Spring Harbor, NY: Cold Spring Harbor Laboratory.

RAO, V. N. \& Bhargava, P. M. (1985). Isolation, characterisation and possible mode of action of antiseminalplasmin - a new protein that inhibits the antimicrobial activity of seminalplasmin. Biochemical Journal 227, 609-619.

RaO, V. N., Reddy, E. S. P., Torriani, A. \& Bhargava, P. M. (1983). Seminalplasmin inhibits transcription and translation of $\phi 80$ DNA in vitro. FEBS Letters 152, 6-10.

Reddy, E. S. P. \& Bhargava, P. M. (1979). Seminal- 
plasmin - an antimicrobial protein from bovine seminal plasma which acts in Escherichia coli by specific inhibition of rRNA synthesis. Nature, London 279, 725-728.

Reddy, E. S. P., DAS, M. R., Reddy, E. P. K. \& Bhargava, P. M. (1983). Inhibition of reverse transcriptase by seminalplasmin. Biochemical Journal 209, 183-188.

Schaller, K., Höltje, J.-V. \& Braun, V. (1982). Colicin $\mathbf{M}$ is an inhibitor of murein biosynthesis. Journal of Bacteriology 152, 994-1000.

Scheit, K. H. \& Bhargava, P. M. (1985). Effect of seminalplasmin, an antimicrobial protein from bovine semen, on growth and macromolecular synthesis in Candida albicans. Indian Journal of Biochemistry and Biophysics 22, 1-7.

SCHEIT, K. H. \& ZIMMER, M. (1984). Seminalplasmin, an antimicrobial protein from bull semen, inhibits gene expression in Escherichia coli. Biochimica et biophysica acta 781, 187-191.

Scheit, K. H., Reddy, E. S. P. \& Bhargava, P. M. (1979). Seminalplasmin is a potent inhibitor of Escherichia coli RNA polymerase in vitro. Nature, London 279, 728-731.

Scheit, K. H., Shivaji, S. \& Bhargava, P. M. (1985). Seminalplasmin, an antimicrobial protein from bull seminal plasma, inhibits growth and synthesis of nucleic acids and proteins in Saccharomyces cerevisiae. Journal of Biochemistry 97, 463-471.

SHIVAJI, S. (1984). Antimicrobial activity of semen. Trends in Biochemical Sciences 9, 104-107.

THEIL, R. \& SCHEIT, K. H. (1983). Amino acid sequence of seminalplasmin, an antimicrobial protein from bull semen. EMBO Journal 2, 1159-1163. 